\begin{tabular}{|l|c|c|c|c|}
\hline $\begin{array}{l}\text { Cuadernos de Investigación Geográfica } \\
\text { Geographical Research Letters }\end{array}$ & 2020 & N $^{\circ} 46(2)$ & pp.521-544 & eISSN 1697-9540 \\
\hline
\end{tabular}

\title{
SURVEYING TOPOGRAPHICAL CHANGES AND CLIMATE VARIATIONS TO DETECT THE URBAN HEAT ISLAND IN THE CITY OF MÁLAGA (SPAIN)
}

\author{
J.M. SENCIALES-GONZÁLEZ1*, J. RODRIGO-COMINO² ${ }^{2}$ P. SMITH ${ }^{3}$
}

\author{
${ }^{1}$ Department of Geography, University of Málaga, 29079 Málaga, Spain. \\ ${ }^{2}$ Department of Physical Geography, University of Trier, 54296 Trier, Germany. \\ ${ }^{3}$ Institute of Biological and Environmental Sciences, University of Aberdeen, 23 St Machar Drive, \\ Aberdeen, AB24 3UU, United Kingdom.
}

\begin{abstract}
The main aim of this research was to detect a possible urban heat island (UHI) in the tourist city of Málaga (Spain). To achieve this goal, different methods to validate annual and monthly temperature data have been used, and the internal variability of the UHI with respect to the topographical changes was also surveyed. Our results showed two types of atmospheric thermal gradients: one characterized by a positive gradient according to an elevation above sea level, and another with a negative gradient related to rural areas. The maximum impact of the UHI was found to be $9.1^{\circ} \mathrm{C}$ for an instantaneous event, $4.4^{\circ} \mathrm{C}$ for daily minimum temperatures in August, with a maximum weighted average difference of $2.3{ }^{\circ} \mathrm{C}$ between data from urban and rural stations. We conclude that the detection of UHI is useful as a tool to help urban planners, in order to reduce the intensity of possible climate changes in cities. It is also concluded that UHI is not only a meteorological phenomenon in Málaga city but a climatic phenomenon, present during most days and across the transect of increasing intensity from the sea to the city.
\end{abstract}

Midiendo los cambios topográficos y las variaciones climáticas para detectar la isla de calor urbano en la ciudad de Málaga (España)

RESUMEN. El principal objetivo de esta investigación es detectar una posible isla de calor urbana (UHI) en la ciudad turística de Málaga (España). Para ello, se han empleado diferentes métodos para validar los datos mensuales y anuales de temperatura, teniendo en cuenta la variabilidad interna de la isla de calor urbana con respecto a los cambios topográficos también analizados. Nuestros resultados indicaron que se pueden detectar dos tipos de gradientes térmicos atmosféricos, uno caracterizado por un gradiente positivo acorde con la elevación con respecto al nivel del mar, y el otro de tipo negativo, relacionado con las áreas rurales. Se ha registrado un máximo de isla de calor de $9,1^{\circ} \mathrm{C}$ para un evento específico, $4,4^{\circ} \mathrm{C}$ para las variaciones mínimas de temperatura en agosto, y un promedio máximo de diferencias ponderadas de hasta $2,3{ }^{\circ} \mathrm{C}$ entre las estaciones 
urbanas y las rurales. Por lo tanto, podemos concluir que la detección de islas de calor podría ser una herramienta útil para los planes de ordenación con objeto de reducir la intensidad de los posibles efectos climáticos sobre las ciudades. Además, también se ha observado que la isla de calor urbana no es solo un fenómeno meteorológico en la ciudad de Málaga, sino un fenómeno de carácter climático, presente la mayoría de los días del año a lo largo de un determinado transecto de intensidad creciente desde el mar hasta la ciudad.

Keywords: Climate Observation, Atmospheric Thermal Gradients, Complex Terrain, Local Climatic Zones, Urban Heat Island.

Palabras clave: Observación Climática, Gradientes Térmicos Atmosféricos, Topografía Compleja, Zonas Climáticas Locales, Isla de Calor Urbana.

*Corresponding author: José María Seciales-González, Department of Geography, University of Málaga, 29079 Málaga, Spain. E-mail address: senciales@uma.es

\section{Introduction}

In the context of global warming, the urban heat island (UHI) effect is an important issue for humankind, though such warming is not restricted to urban areas (McKitrick and Michaels, 2007). The UHI can be defined as the temperature difference between the urban-suburban and rural areas in the same region (Ningrum, 2018). The intensity of each UHI is confirmed through the temperature difference expressed at a given time between the hottest sector of the city and the non-urban space surrounding (Martín-Vide et al., 2015).

Numerous studies have focused on documenting the impact of urbanization on local temperatures in specific areas considering diverse environmental (Mayer and Höppe, 1987; Lin et al., 2008; Corumluoglu and Asri, 2015; Edmondson et al., 2016), economic (Rizwan et al., 2008) or socioeconomic effects (Buyantuyev and $\mathrm{Wu}, 2010$ ). However, urban planners do not usually use such studies when developing urban and tourist plans (Lin and Matzarakis, 2008; Matzarakis, 2010). Since the pioneer investigations carried out in London (Howard, 1818; Chandler, 1965), further investigations focused on wellknown UHI have been conducted using different methodologies around the world, included Spain; unless they are relevant for their methodology or results, they have not been further discussed in this study due to limited space.

The methods used to measure UHI are diverse. Remote sensing data are commonly used to assess UHI (Chen et al., 2006; Sobrino et al., 2013), though datasets with a high spatiotemporal resolution remain rare (Pérez-González et al., 2003; Gomes and Amorim, 2015). The use of Geographical Information Systems (GIS) (Aniello et al., 1995; Lo et al., 1997) as well as climate simulations (McCarthy, et al., 2010; Giovannini, et al., 2014), analysis of thermal data transects (Bello Fuentes, 1994; Torok et al., 2001; 
Vicente-Serrano et al., 2005; Serra Pardo, 2007; Moreno García and Serra Pardo, 2016; Sánchez-Guevara et al., 2017) or data distribution from public and private nets (Chen and Jeong, 2018; Jhaldiyal et al., 2018) and mixed methods (Peterson and Owen, 2005), have also been applied in UHI studies.

Regardless, topography and winds can be considered the key factors in thermal variability (Goldreich, 1984; Thompson et al., 2007; Ribeiro et al., 2018). In urban and rural areas, thermal variability affects specific increases or decreases in temperature of concrete (Tabony, 1985; Suomi, 2014; Ketterer and Matzarakis, 2014; Miao et al., 2015) and temperature differences between rural and urban areas (Zeleňáková, et al., 2015).

The city of Málaga (South of Spain) represents a clear example of urban development resulting from favourable climatic aspects and, consequently, a boom in tourism (MarínCots et al., 2008). In addition, the development of a new international passenger terminal at the airport in 1991, has seen Málaga grow from 522,108 inhabitants (IECA, 2018) with 2 million air passengers in 1990, to 569,002 inhabitants with 18.6 million air passengers in 2017 (AENA, 2018). There are no previous studies on UHI in Málaga, and it is a good case study for a rapidly developing city.

Thus, the main aims of this study are to assess: i) the internal variability of the climatic variables (temperatures, humidity, winds) and their possible connection with topographical changes; and, ii) to identify evidence for a UHI in Málaga city and its hinterland.

\section{Materials and Methods}

\subsection{Study Area}

The city of Málaga is located on the shore of the Alboran Sea (western end of the Mediterranean Sea). It occupies 7225 ha (Ayuntamiento de Málaga, 2015) and it extends from the eastern side of the Guadalhorce River to the foot of a hilly area known as the "Montes de Málaga" which is a physiographic unit that slightly exceeds $1000 \mathrm{~m}$ a.s.l. in altitude across $11.6 \mathrm{~km}$ of longitude. The minimum elevation of the city is located at the shore of the sea, while the highest level is at $200 \mathrm{~m}$ a.s.l. in the north-western corner of the city (Fig. 1). The predominant exposure towards the south provides a high degree of insolation. The relief includes moderate slopes around the city, with gradients from 21 to $30 \%$, except in the Guadalhorce valley, where the inclination does not exceed 3\%. The Guadalhorce River forms a narrow valley with a fluvial plain with a width of less than $7 \mathrm{~km}$, which can channel winds and thermal inversions near the coast along the valley (Rodrigo-Comino et al., 2014).

Málaga registers 2905 hours of sunshine per year (AEMET, 2019). The annual total rainfall oscillates from 400 to $700 \mathrm{~mm}$, showing the maximum values at the top of the Montes de Málaga. The mean annual humidity values are around 65\%, and the annual mean values of wind speed vary from 0.5 to $3.7 \mathrm{~m} / \mathrm{s}$. The direction of the winds is considered as a variable throughout the year: maritime (Eastern-South-eastern winds) in summer, and continental (Western-North-western winds) in winter. Maritime breezes 
are common during the day-time, but at the night-time continental breezes are usual, reducing the moderating effect of the sea during the coldest hours of the day.

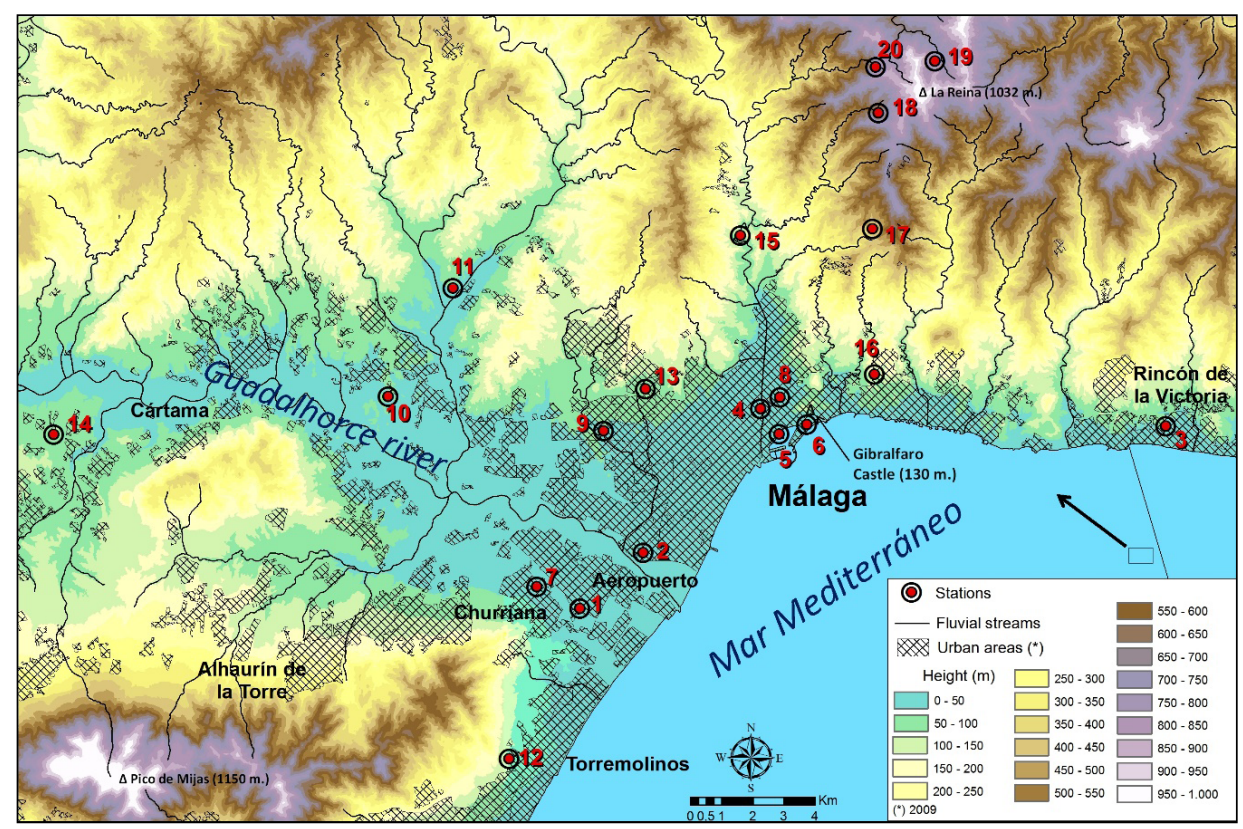

Figure 1. Topographic map of Málaga city showing the location of the climate stations.

\subsection{Data pre-treatment and validation}

All the available thermometric data situated in the climate stations around (thirteen stations), peripheral (four stations) and within (six stations) the city were used. All the datasets have sufficiently long series (at least five complete years) to be validated by standardized methods (Alexandersson and Moberg, 1997; Domonkos and Štěpánek, 2009) (Equation 1)

$$
Q i=\frac{Y i}{(r 2 * X j i * Y) /(X j * r 2)}
$$

$Q i=$ Normalized value (usually around 1)

$Y i=$ Specific value of the dependent dataset

$r 2=$ Correlation coefficient between the selected site and a surrounding station (reference station)

$X j=$ Annual mean temperature of a surrounding station

$X j i=$ corresponding value of the surrounding station 
The dataset is currently curated by the Andalusian network of environmental information ("REDIAM") and is publicly available (Junta de Andalucía, 2018).

Two control stations were used to apply the Standard Normal Homogeneity Test (SNHT) and to calculate data gaps (Schneider, 2001; Mirón-Pérez et al., 2006). These control stations are close to each other $(<30 \mathrm{~km})$ and have 30 complete years $(1988$ 2017) of daily data (average, maximum and minimum temperatures) without gaps or inhomogeneities. To qualify as a control station, a positive correlation $>35 \%$, with $<10 \%$ of data omissions, and >30-years of data was required (Eischeid et al., 2000; Prieto et al., 2004). To fill the dataset gaps using one station, the Normalized Ratio (NR) method was applied (Paulhus and Kohler, 1952) (Equation 2):

$T p=\frac{1}{n}+\llbracket\left(\frac{T x}{T x 1}\right) * T 1+\left(\frac{T x}{T \times 2}\right) * T 2+\cdots+\left(\frac{T x}{T x n}\right) * T n \rrbracket$

$T p=$ Mean monthly temperature without data of a specific year.

$n=$ Number of reference stations.

$T x=$ Mean monthly temperature without data from the used dataset.

$T x 1, T x 2, T x n=$ Mean monthly temperature without data from the used dataset of the reference station number $1,2 \ldots n$.

$T 1, T 2 \ldots$ Tn $=$ Mean monthly temperature without data from a specific year of the reference station number $1,2 \ldots \mathrm{n}$.

This method, usually applied to calculate rainfall gaps in mountainous areas, can also be applied for temperature, insolation and pressure interpolations (BarreraEscoda, 2004). If two control stations can be used to fill the dataset gaps, a multiple linear regression method can be used (Eischeid et al., 2000; González-Hidalgo et al., 2002).

Several stations obtained a high correlation with the complete stations and had an extensive dataset ( $>25$ years with daily data), where the few monthly gaps were filled to get 30 years of data (1988-2017). The NR method was used to calculate missing data (see above Equation 2).

After this step, the focus was on completing the dataset for annual data for the rest of the stations, using the SNHT (Domonkos and Štěpánek, 2009; Alexandersson, 2001; Aguilar-Anfrons et al., 2002) (Equation 3):

$$
x=\frac{\left.\sum_{j=1}^{\mathrm{k}} \mathrm{r} 2 \mathrm{j}(\mathrm{yj}+\mathrm{X}-\mathrm{Yj})\right)}{\sum_{\mathrm{j}=1}^{\mathrm{k}} \mathrm{r} 2 \mathrm{j}}
$$

$X=$ value of the variable to be homogenized.

$r 2 j=$ correlation coefficient between a series of variable and control series.

$y j=$ control value in the year with lacks. 
$X$ and $Y j=$ mean of series to be homogenized and mean of control series.

SNHT revealed important anomalies in six additional stations; so these stations were discarded. The metadata was also analysed to verify that there were no changes in the location of any other stations and if so, to refer to it as a different station (AguilarAnfrons et al., 2002). Sometimes, it was necessary to discard the initial years of the series due to instrument calibration errors.

After applying all validation methods, 30-years of daily data were obtained for 20 stations (Fig. 1). The same methods were applied to maximum and minimum average temperatures, means, and extreme (maximum and minimum) values for the 30 -year period. For wind speed and humidity, a minimum of six years in the series was filled (Table 1). The metadata can be seen in Table 1 as well as the characteristics of the stations following the concept of local climate zones (LCZ) (Stewart et al., 2014).

Table 1. Metadata of the climate stations used.

\begin{tabular}{|c|c|c|c|c|c|c|c|}
\hline ID & Name & $\begin{array}{c}\text { Distance to the } \\
\text { sea }(\mathrm{km})\end{array}$ & Height (m) & Years & Series & Station type & LCZ \\
\hline 1 & Aeropuerto & 2.3 & 7 & 74 & $1942-2017$ & TG-R-H-W & $8-\mathrm{E}$ \\
\hline 2 & Azucarera & 1.8 & 10 & 22 & $1972-1993$ & T-R & 8-B \\
\hline 3(@) & Rincón & 0.2 & 10 & 17 & 1998-2017 & TG-R-H-W & $6-B$ \\
\hline $4(*)$ & Carmelitas & 1.0 & 12 & 31 & 1987-2017 & TG-R & $2-\mathrm{E}$ \\
\hline $5(*)$ & Puerto & 0.06 & 20 & 17 & 2001-2017 & TG-R-H-W & $5-\mathrm{B}$ \\
\hline $6(*)$ & CASE & 0.2 & 25 & 8 & 2010-2017 & TG-R-H-W & $2-\mathrm{E}$ \\
\hline 7 & Churriana & 4.0 & 32 & 40 & 1977-2017 & TG-R-H-W & 9-B \\
\hline $8(*)$ & Málaga-Ciudad & 1.2 & 53 & 92 & $1878-1986$ & $\mathrm{~T}-\mathrm{R}$ & $2-B$ \\
\hline $9(\#)$ & Cónsul & 4.6 & 56 & 17 & 2001-2017 & TG-R-H-W & $5-\mathrm{C}$ \\
\hline 10 & Campanillas & 11.2 & 60 & 8 & 2007-2017 & TG-R-H-W & 9-B \\
\hline 11 & Málaga-RIA & 11.3 & 68 & 17 & 2001-2017 & TG-R-H-W & 9-B \\
\hline 12(@) & Torremolinos & 2.2 & 85 & 9 & 2009-2017 & TG-R-H-W & $2-\mathrm{E}$ \\
\hline $13(\#)$ & Atabal & 4.2 & 90 & 12 & 2006-2017 & TG-R-H-W & 8-C \\
\hline 14 & Cártama-RIA & 19.9 & 95 & 16 & 2002-2017 & TG-R-H-W & 9-B \\
\hline 15 & Agujero & 6.7 & 100 & 17 & 1966-1984 & $\mathrm{T}-\mathrm{R}$ & 9-B \\
\hline $16\left(^{*}\right)$ & Calderón & 1.4 & 129 & 5 & 2007-2015 & $\mathrm{T}-\mathrm{R}$ & 6-B \\
\hline 17 & Boticario & 6.1 & 450 & 41 & $1950-2017$ & T-R & 9-A \\
\hline 18 & Cerrado & 9.9 & 635 & 31 & 1986-2016 & T-R & 9-A \\
\hline 19 & Torrijos & 11.8 & 718 & 45 & 1956-2014 & T-R & 9-A \\
\hline 20 & Contadoras & 11.4 & 760 & 57 & 1950-2017 & $\mathrm{T}-\mathrm{R}$ & 9-A \\
\hline
\end{tabular}

$\mathrm{T}=$ Temperature; $\mathrm{TG}=$ Temperature from thermographic device registering ten-minute data; $\mathrm{R}=$ Rainfall; $\mathrm{H}=$ Humidity; W=Wind; (*) Station located in the inner-city area. (\#) Peripheral Urban stations. (@) Periurban stations. $\mathrm{LCZ}=$ Local Climate Zones 
Prior to analysing the data, the reliability of the extrapolation was checked using a post hoc t-test and chi-squared, determining differences between the average values and contrasting observed and predicted frequencies. The null hypothesis was rejected for alpha values equal to 0.05 , supposing a level of confidence of $95 \%$. All of these statistical analyses were performed with the software Statgraphic v.17.0.

\subsection{Temperature gradients in Málaga city}

After validating the data, it is necessary to analyse the influence of topography on the distribution of temperatures. Firstly, linear correlations between elevation above sea level and temperature were performed, the latter being the dependent variable. It is usual to consider that temperatures drop linearly according to elevation, by $0.65{ }^{\circ} \mathrm{C}$ for each $100 \mathrm{~m}$ (Barry and Chorley, 2009), but the value of that gradient may be variable (Hufty, 1975; Rodrigo-Comino, 2012) or even inverse (García-Guadalupe et al., 2012; Mason et $a l, 2017$ ), especially with minimum temperatures (Tabony, 1985).

For this reason, in Málaga city, it was necessary to clarify the presence or absence of thermal inversion at the bottom parts for calculating the real gradient. To achieve this goal, several adjustment maps were prepared using a Digital Terrain Model (DTM) with a 5-meter resolution to get the best possible accuracy. These adjustments used virtual stations from different urban, peri-urban and rural gradients close to the city (Mason et al., 2017).

Different gradients and maps using mean annual (Figs. 2 and 3), average minimum daily (Fig. 4), and average maximum daily temperatures (Fig. 5) were obtained for urban, rural and all stations. They were used to calculate new values for virtual stations located in urban, peri-urban and rural areas at different heights and types of thermal values. The maps were made using the software Arc-Map 10.5.1 (ESRI, USA). 180 virtual stations were added to the original 20 stations. The data of these virtual stations have been calculated according to the different gradients obtained in urban, peri-urban (general gradient using all stations) and rural areas. Then, Universal Kriging (Crawford, 2001 ) with anisotropy and 8 sector neighbourhoods was applied; this procedure reduces the root mean square error (RMSE) by 0.2 points from the cross-validation method. It was compared with Ordinary Kriging and Map Algebra methods.

\subsection{UHI calculations}

In order to analyse real thermal differences between urban and non-urban areas, various procedures have been used. The weight of the temperature differences between stations located at the same level and distance from the sea were sought, distinguishing between urban and non-urban stations. Daily data from stations with ten-minute thermographic data were used; thus, it was possible to find the maximum difference at a given time, clarifying the difference between values. Winds, humidity, pressure and weather type were also identified for each moment. Twelve cases (one for each month) were selected from fixed dates identified as having the highest daily thermal differences between stations. 
The Oke (1978), Karl et al. (1988) and Torok et al. (2001) methods were applied to make an approximation to the impact of the size of the city on UHI, and compare the expected results to those obtained for the analysis related to the real thermal data:

Oke (1978) method (Equation 4):

$\Delta \mathrm{T}_{\mathrm{u}-\mathrm{r}}=2.01 \log \mathrm{P}-4.06$

Karl et al., (1988) method (Equation 5):

$\Delta \mathrm{T}_{\mathrm{u}-\mathrm{r}}=\mathrm{a} \cdot \mathrm{P}^{0.46}$

Torok et al., (2001) method (Equation 6):

$\Delta \mathrm{T}_{\mathrm{u}-\mathrm{r}}=1.42 \log \mathrm{P}-2.09$

Where $\Delta T_{\mathrm{u}-\mathrm{r}}=$ Temperature difference between the urban and rural area

$P=$ Population (number of inhabitants of the city)

$a=$ empirical coefficient, usually $1.82 \cdot 10^{-3}$,

Several authors have also added the night-time and seasonal UHI (Capelli de Steffens et al., 2005; Alcoforado and Andrade, 2006; Bahi et al., 2017) finding important differences between this analysis and the results of annual UHI. In addition, several authors have even demonstrated that the UHI effect overturns in certain hours of the day (normally at midday) (Ningrum, 2018), with variations across the year (Chen and Jeong, 2018). Therefore, the same differences (rural-urban) were measured using the fixed time of maximum difference.

\section{Results}

\subsection{Data pre-treatment}

In Table 1, five LCZ (Stewart et al., 2014) are registered: 2, 5, 6, 8 and 9. LCZ 2 shows compact urban areas with mid-rise buildings which include several urban and peri-urban stations $(4,6,8)$ and station 12 . LCZ 5 shows open mid-rise buildings with only two urban stations. LCZ 6 summarises urban areas but open low-rise buildings. LCZ 8 includes non-urban zones with large low-rise buildings. Finally, LCZ 9 has only rural stations in sparsely built areas.

Table 2 shows summarise the average value of the mean annual, daily minimum and daily maximum temperatures from 1988 to 2017. Data values for one or several months during some years were gap-filled using NR at several stations, but most gap fillings were done using SNHT. Data show a mean difference of $4.8^{\circ} \mathrm{C}$ between the maximum and the minimum mean annual value, due to topographical factors; but the maximum difference between stations at the same level is $2^{\circ} \mathrm{C}$ (average of mean annual temperature) and $4.2{ }^{\circ} \mathrm{C}$ (average of daily minimum temperatures). Nevertheless, the 
maximum difference between stations at the same level is $2.8{ }^{\circ} \mathrm{C}$ for an average of daily maximum temperatures.

Table 2. Summary of the average annual temperatures and methods of interpolation for climate stations 1 to 20 from 1988 to 2017.

\begin{tabular}{|c|c|c|c|c|c|c|c|c|c|c|c|c|c|c|c|c|c|c|c|c|}
\hline $\mathrm{ID}$ & 1 & 2 & 3 & 4 & 5 & 6 & 7 & 8 & 9 & 10 & 11 & 12 & 13 & 14 & 15 & 16 & 17 & 18 & 19 & 20 \\
\hline Annual Mean $\mathrm{T}\left({ }^{\circ} \mathrm{C}\right)$ & 18.7 & 18.0 & $\underline{18.7}$ & 19.0 & $\underline{19.2}$ & $\underline{19.2}$ & 18.3 & 19.4 & $\underline{19.3}$ & $\underline{18.2}$ & $\underline{18.3}$ & $\underline{19.0}$ & $\underline{18.1}$ & $\underline{17.9}$ & [17.7 & $\underline{19.1]}$ & $\underline{17.6}$ & 15.7 & $\underline{14.9}$ & 16.1 \\
\hline $\begin{array}{l}\text { Number of } \\
\text { extrapolated years }\end{array}$ & & $\underline{30}$ & $\underline{13}$ & & $\underline{13}$ & $\underline{22}$ & & $\underline{30}$ & $\underline{13}$ & $\underline{22}$ & $\underline{13}$ & $\underline{21}$ & $\underline{18}$ & $\underline{14}$ & $\underline{30}$ & $\underline{25}$ & $\underline{15}$ & & $\underline{3}$ & \\
\hline $\begin{array}{c}\text { Number of interpolated } \\
\text { years }\end{array}$ & & & (1) & (6) & (2) & & & & & & & & & & & (2) & (2) & (7) & (7) & (6) \\
\hline Daily Min. $T\left({ }^{\circ} \mathrm{C}\right)$ & 14.1 & 12.9 & 14.9 & 15.6 & 16.0 & 16.2 & 13.5 & 14.5 & 15.1 & 12.8 & 12.8 & 14.5 & 14.9 & 11.9 & $\underline{\underline{I 10}}$ & [6.1] & 13.0 & 10.7 & 9.9 & 10.8 \\
\hline Daily Max. T $\left({ }^{\circ} \mathrm{C}\right)$ & 23.5 & 23.0 & 22.1 & 22.2 & 23.2 & 22.1 & 23.4 & $\underline{\underline{0113}}$ & 23.8 & $\underline{\underline{24.1}}$ & 23.9 & 22.7 & 22.0 & 24.6 & 23.5 & 23.4 & 22.1 & 20.7 & 20.0 & 21.2 \\
\hline
\end{tabular}

Bold: Reference Stations; Underlined: annual extrapolation using SNHT; Shaded: monthly interpolation using NR. Reverse colour the maximum difference between temperatures values among stations at the same level. Daily Min. $\mathrm{T}\left({ }^{\circ} \mathrm{C}\right)$ : Daily minimum temperature. Daily Max. $\mathrm{T}\left({ }^{\circ} \mathrm{C}\right)$ : Daily maximum temperature.

\subsection{Temperature gradients in Málaga city}

Figure 2 shows four types of mean annual temperature gradients in Málaga city and its hinterland. The first of them (urban stations; $\mathrm{R}^{2}=0.91 ; \Delta=0.57 \cdot 100^{-1} \mathrm{~m}$ ) follows an inverse gradient. The second $\left(\mathrm{R}^{2}=0.89 ; \Delta=-0.6 \cdot 100^{-1} \mathrm{~m}\right)$ includes only urban stations and two rural stations situated at more than $600 \mathrm{~m}$ a.s.l. The third one excludes all the urban stations $\left(\mathrm{R}^{2}=0.87 ; \Delta=-0.29 \cdot 100^{-1} \mathrm{~m}\right)$. Finally, the worst adjustment uses all the stations $\left(\mathrm{R}^{2}=0.77 ; \Delta=-0.45 \cdot 100^{-1} \mathrm{~m}\right.$.).

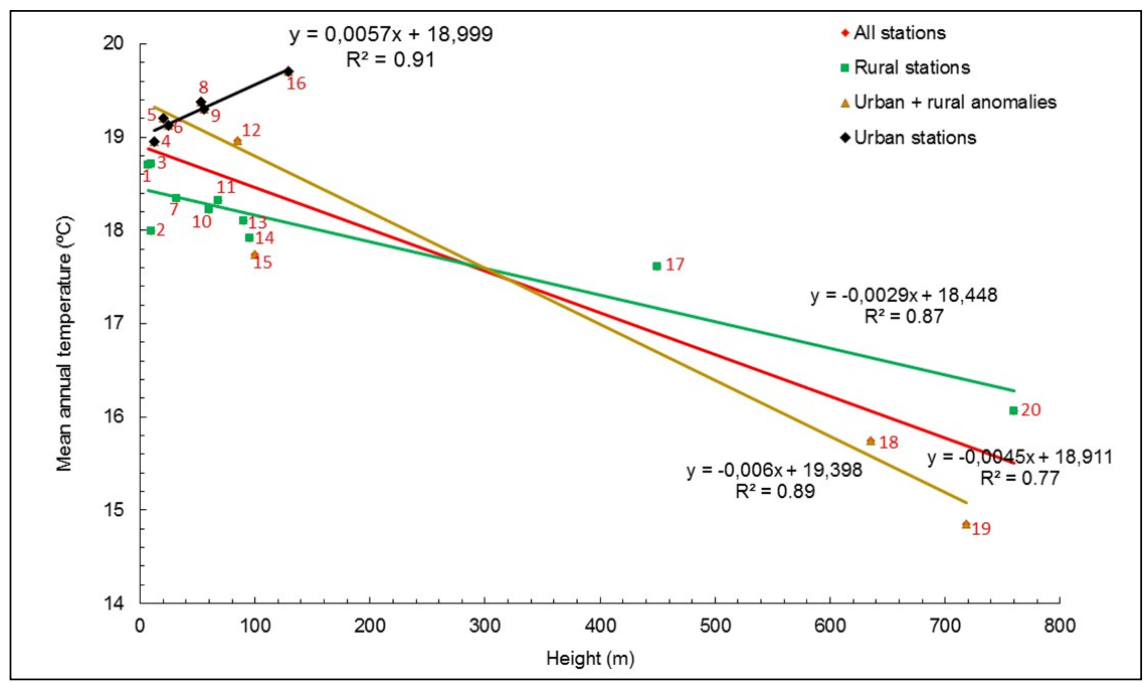

Figure 2. Different gradients identified in Málaga city using the mean annual temperatures from each climate station. 
However, these gradients are different when analysing the average of the daily minimum and maximum temperatures. There is no valid gradient in urban areas: $\mathrm{R}^{2}=0.013 ; \Delta=-0.18 \cdot 100^{-1} \mathrm{~m}$ for minimum temperatures; $\mathrm{R}^{2}=0.056, \Delta=0.5 \cdot 100^{-1} \mathrm{~m}$ (inverse gradient) for maximum temperatures; but the rural gradient has better adjustment than using mean annual temperature: $\mathrm{R}^{2}=0.903, \Delta=-0.37 \cdot 100^{-1} \mathrm{~m}$ for minimum temperatures, and $\mathrm{R}^{2}=0.88, \Delta=-0.38 \cdot 100^{-1} \mathrm{~m}$ for maximum temperatures. A correlation of $\mathrm{R}^{2}=0.527$ and a gradient of $\Delta=-0.55 \cdot 100^{-1} \mathrm{~m}$ is achieved using all stations for minimum temperatures and $\mathrm{R}^{2}=0.48, \Delta=-0.337 \cdot 100^{-1} \mathrm{~m}$ for maximum temperatures.

\subsection{UHI calculations}

Table 3 shows the weighted average of differences between minimum daily values of urban and non-urban stations (values in ${ }^{\circ} \mathrm{C}$ ) located at the same level and distance from the sea. Weighted averages were obtained from all available daily data of minimum values from the ten-minute thermographic series. These data contrast with those reflected in Table 4, reducing differences between stations.

Table 3. Weighted average of differences between minimum daily values of urban and not-urban stations

\begin{tabular}{|l|c|c|c|c|c|}
\hline & \multicolumn{4}{|c|}{ Rural stations } & Peri-urban station \\
\hline Urban Station (A) & 1 & 7 & 10 & 11 & 3 \\
\hline 4 & 1.60 & & & & 0.69 \\
\hline 6 & 1.54 & & & & 1.66 \\
\hline 9 & & 1.66 & 2.30 & 2.27 & \\
\hline
\end{tabular}

$\sum$ (A-B)/Total cases (values in ${ }^{\circ} \mathrm{C}$ ).

All urban stations show a positive difference with respect to non-urban stations.

Three different UHI realisations were obtained. The Oke (1978) method establishes a maximum difference between rural and urban zone applied to Málaga of $7.5^{\circ} \mathrm{C}$. The Karl et al. (1988) method obtains a maximum difference of $0.8^{\circ} \mathrm{C}$. Finally, the Torok et al. (2001) method shows a maximum difference of $6.1^{\circ} \mathrm{C}$. We compared these results with the real maximum difference between measured temperatures in Málaga city using several types of data: average and fixed daily data.

Figure 3 and Table 2 use annual mean temperatures. It is necessary to emphasize that maximum difference between urban and rural stations reaches exactly $2{ }^{\circ} \mathrm{C}$ in $5 \mathrm{~km}$., but near the sea, the maximum difference is only $1{ }^{\circ} \mathrm{C}$. Next to the urban area, a "cool island" is observed, due to a wooded hill whose summit is the Castle of Gibralfaro (130 m a.s.l.). 


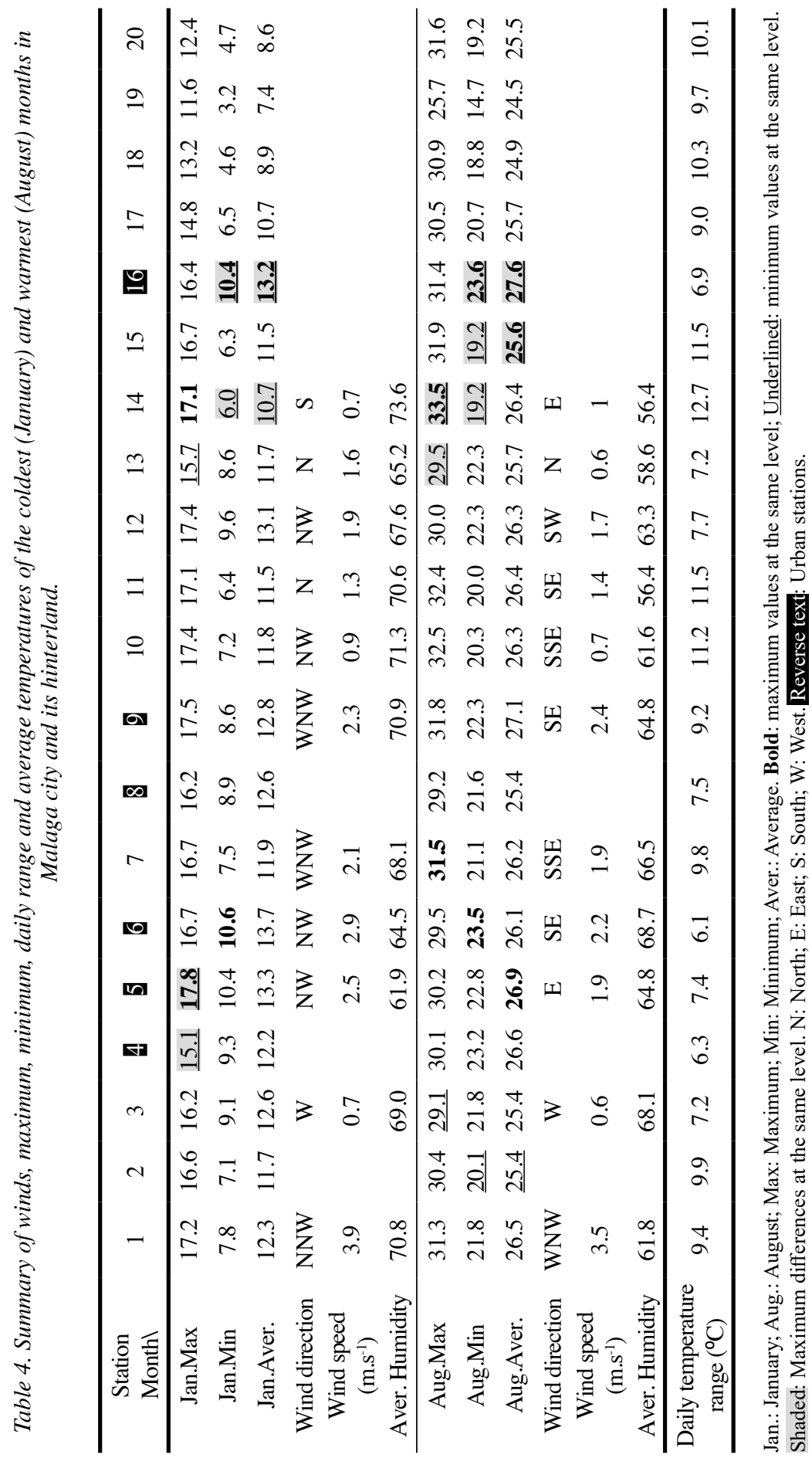




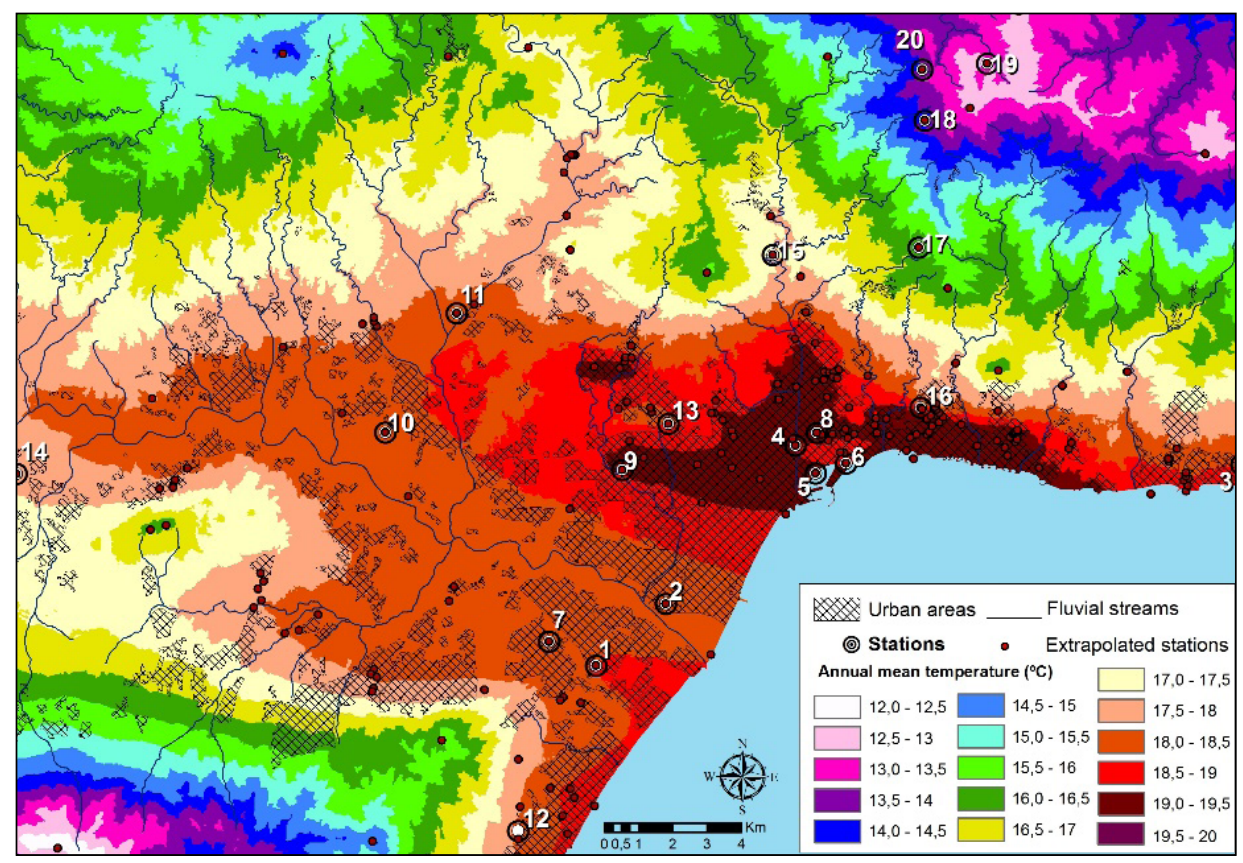

Figure 3. Map of the annual mean temperature of Málaga city.

Figure 4 and Table 2 show the differences in average minimum daily temperatures; in this case, differences increase up to $4.2^{\circ} \mathrm{C}$. Again, close to the sea, the differences are reduced to $3.3^{\circ} \mathrm{C}\left(2.7^{\circ} \mathrm{C}\right.$ if the stations 2 and 4 were compared $)$.

Figure 5 and Table 2 show the differences in average maximum daily temperatures. Contrary to previous data, maximum values are obtained in rural zones, although there are no clear trends due to the absence of a valid gradient in urban areas. In any case, maximum differences are $2.8^{\circ} \mathrm{C}$. A minor difference is obtained close to the sea $\left(1.3^{\circ} \mathrm{C}\right)$. Thus, the UHI disappears at midday. An exception can be highlighted in this case: station 9 (urban zone) shows a higher average maximum daily temperature than station 7 (rural zone). Several effects (not exclusive to each other) could explain this exception: i) the winds in summer and during the most of daytime in the year blow from the sea at both stations, but there is a reduction of the effects of the sea breezes (with a lower humidity) in the urban station, due to the continuous presence of buildings from station 9 to the sea, as can be seen also in station 13 (Table 4); ii) the closest proximity to other high-temperature stations of the Guadalhorce valley (Fig. 1), combined with a slightly higher sun exposure compared with station 7; and iii) the position of the station 9 in the boundary of the city, with midrise buildings, bushes and small trees, but next to wasteland and peri-urban open fields. 


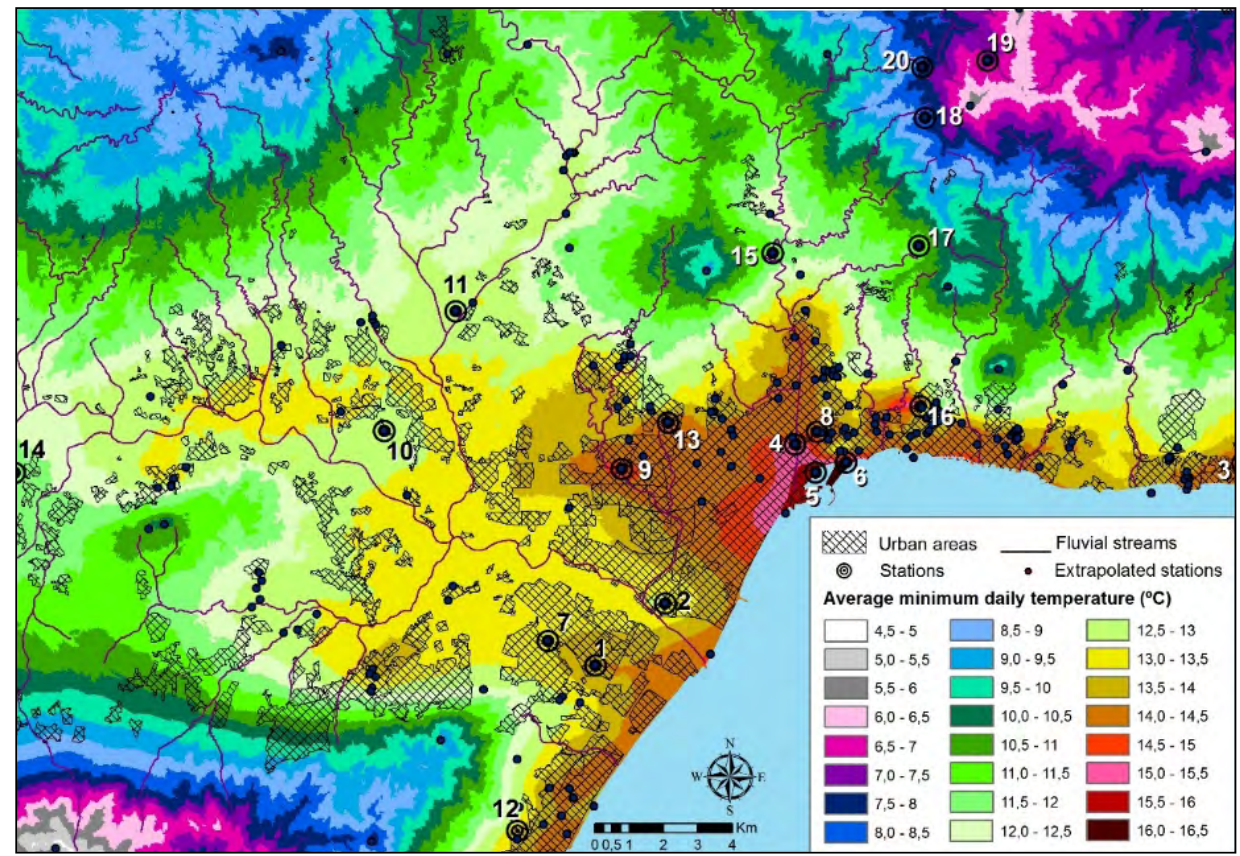

Figure 4. Map of the average minimum daily temperature of Málaga city.

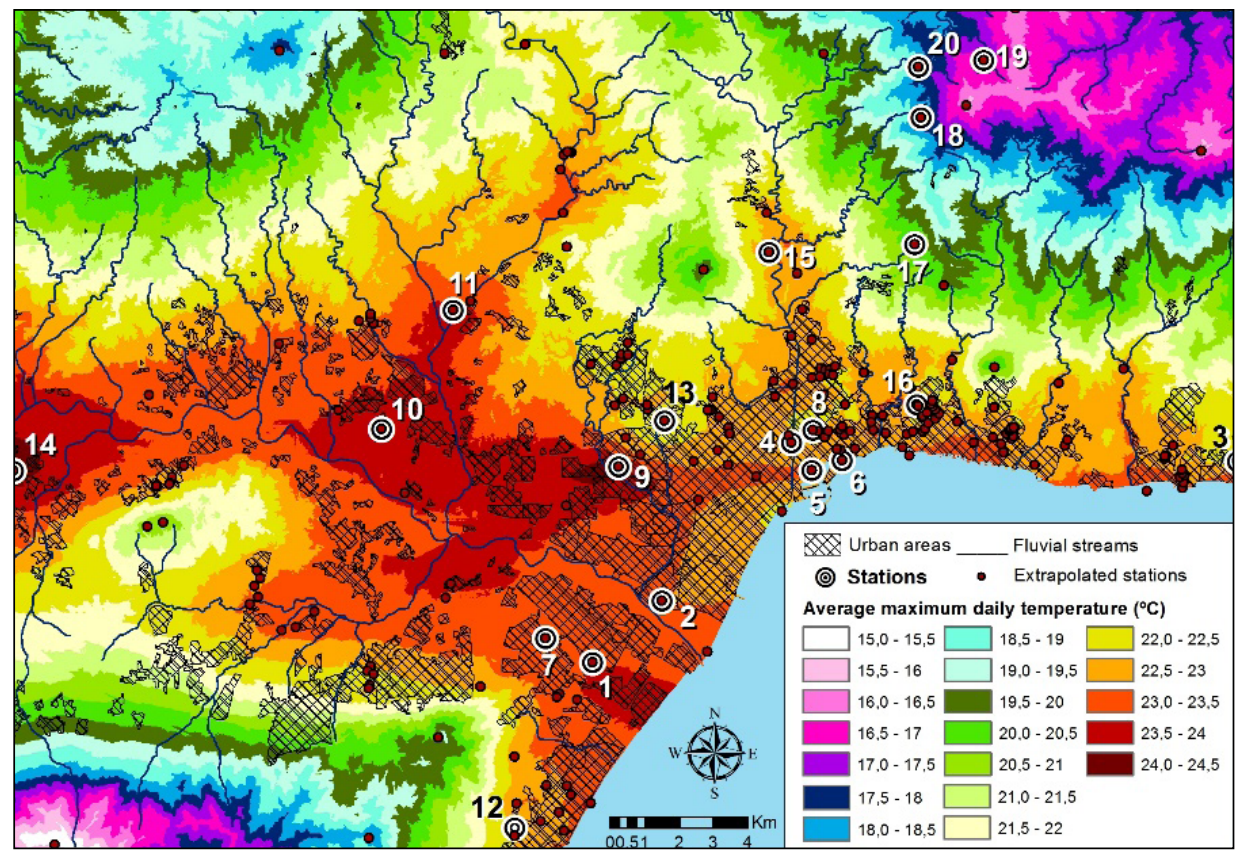

Figure 5. Map of the average maximum daily temperature of Málaga city. 
Furthermore, Table 4 shows the main differences between maximum, minimum and average, comparing the coldest (January) and the warmest (August) month. Thus, using these data, the maximum differences reached at minimum temperatures of August are $4.4^{\circ} \mathrm{C}$. A large distance to the sea could be decisive.

Finally, Table 5 shows the maximum differences between urban and nonurban stations in fixed-hour and date-registered data over all the analysed series with thermographic data, compared the same level and distance from the sea.

Table 5. Maximum differences between urban and not-urban stations in specifics dates and hour.

\begin{tabular}{|c|c|c|c|c|c|c|c|c|c|c|}
\hline \multirow{2}{*}{$\begin{array}{l}\text { Hour and date of maxi- } \\
\text { mum differences }\end{array}$} & \multicolumn{10}{|c|}{ Differences between urban $(A)$ and not-urban stations $(B)$ in ${ }^{\circ} C$} \\
\hline & $\begin{array}{l}\text { A - B } \\
6-3 \\
\end{array}$ & $\begin{array}{l}\text { A-B } \\
4-1 \\
\end{array}$ & $\begin{array}{c}\text { A-B } \\
4-3 \\
\end{array}$ & $\begin{array}{l}\text { A-B } \\
9-7\end{array}$ & $\begin{array}{l}A-B \\
9-10 \\
\end{array}$ & $\begin{array}{l}\text { A-B } \\
9-11 \\
\end{array}$ & $\begin{array}{c}\text { Wind } \\
\text { direction }\end{array}$ & $\begin{array}{c}\text { Wind speed } \\
\left(\mathrm{m} \cdot \mathrm{s}^{-1}\right)\end{array}$ & $\begin{array}{c}\text { Humidity } \\
(\%)\end{array}$ & $\begin{array}{c}\text { Pressure } \\
(\mathrm{HPa})\end{array}$ \\
\hline 6:00:10/01/2009 & & 2.9 & 2.8 & 1.7 & 9.1 & 4.6 & 290 & $2.7-4.7$ & 75 & 1018.7 \\
\hline $7: 40: 25 / 02 / 2012$ & 3.8 & 2.4 & 1.8 & 3.6 & 3.7 & 4.9 & 330 & $0.4-4.5$ & $43-53$ & 1027.2 \\
\hline $6: 30: 15 / 03 / 2012$ & 0.3 & 3.5 & -0.1 & 2.4 & 3.1 & 2.6 & Variable & $0-3.7$ & $48-76$ & 1025.1 \\
\hline 5:50:05/04/2017 & 2.4 & 3.7 & 0.7 & 4.2 & 2.7 & 2.8 & $290-360$ & $0.3-4.7$ & $51-73$ & 1017.8 \\
\hline 16:30:07/05/2009 & & 1.9 & 0.7 & 5.8 & 5.4 & 5.7 & $120-190$ & 2.2 & 50 & 1017.2 \\
\hline $6: 00: 28 / 06 / 2015$ & 7.4 & 1.1 & 2.7 & 4.4 & 2.8 & 5 & Variable & $0.2-3.6$ & $30-49$ & 1018.5 \\
\hline 18:00:11/07/2008 & & 3.1 & 6.7 & -2.5 & -1.6 & 0.2 & Variable & $2.8-8.9$ & $21-52$ & 1009.3 \\
\hline 5:40:09/08/2017 & 2.7 & & & 2.9 & 4.7 & 6.3 & $290-15$ & $0.3-1.5$ & $29-42$ & 1015.0 \\
\hline 16:30:09/09/2011 & 5.2 & 0.6 & 3.5 & 2.1 & & 2.7 & $290-350$ & $2.6-3.9$ & $27-39$ & 1011.5 \\
\hline 7:00:29/10/2017 & -2.4 & 2.2 & -2.4 & 1.9 & 2.1 & 4.2 & $211-357$ & $0.1-3.2$ & $78-100$ & 1020.8 \\
\hline 5:50:21/11/2017 & 1.7 & 3.1 & -1 & 3.9 & 2 & 5.1 & $236-255$ & $0.6-5.5$ & $45-77$ & 1018.2 \\
\hline $10: 30: 15 / 12 / 2015$ & 4.2 & & & 4.3 & 3.4 & 3 & Variable & $0.1-2.7$ & $36-60$ & 1027.7 \\
\hline$\%$ Cases $\mathrm{A}>\mathrm{B}\left(>1{ }^{\circ} \mathrm{C}\right)$ & 64.1 & 66 & 43.7 & 75.1 & 88.2 & 84.4 & & & & \\
\hline$\%$ Cases $\mathrm{A}<\mathrm{B}\left(>1{ }^{\circ} \mathrm{C}\right)$ & 2.2 & 9 & 16.3 & 1 & 0.3 & 0.2 & & & & \\
\hline$\%$ Cases $\mathrm{A} \approx \mathrm{B}\left(<1{ }^{\circ} \mathrm{C}\right)$ & 33.7 & 25 & 39.9 & 23.9 & 11.5 & 15.4 & & & & \\
\hline
\end{tabular}

Hollow: Data no available. Urban stations used (A) to compare: 4, 6 and 9; Not-Urban stations (B): 1, 3, 7, 10 and 11 .

The maximum difference of analysed data is reached during night time in the winter $\left(9.1^{\circ} \mathrm{C}\right)$, under anticyclonic conditions, continental winds, medium wind speed and medium humidity. This value is higher than that calculated using the Oke method. In addition, each pair of stations show maximum differences in different months; nevertheless, it is usual that the maximum number of UHI cases occur in the winter or in the autumn, except for stations 6 (urban) and 3 (peri-urban), that occur in the summer. The probability of daily differences $>1{ }^{\circ} \mathrm{C}$ between station 9 and station 10 is $88.2 \%$ (the highest value between urban-not urban stations); the probability of differences $>6{ }^{\circ} \mathrm{C}$ 
is $3.6 \%$, with a weighted average difference of $2.3{ }^{\circ} \mathrm{C}$. Station 9 (urban) shows the maximum differences when compared with nearest non-urban stations (stations 7,10 and 11); urban stations 4 and 6, closer to the sea, do not usually show such high differences. In fact, although the UHI remains, the proximity to the sea can reduce the effect of building typology (LCZs): stations 4 and 5 (LCZ 2E, compact buildings without trees or scrubs) should show maximum differences, but the highest differences were observed at station 9 (LCZ 5 C, open midrise buildings with bushes).

Nevertheless, on some days, differences are inverse (non-urban zones have higher values than urban zones), but this is an infrequent phenomenon: between station 4 and 3 it happens with a probability of $16.3 \%$, between station 4 and 1 (near to the sea) it reaches a probability of $9 \%$, and between station 9 , and 7, 10 and 11 (urban $v s$. rural stations) it is limited to $\leq 1 \%$. That is, the overturn of UHI in areas near the sea is more likely than in inland areas. It is frequent that the warm winds from inland push the warm water out to sea and cause upwelling (cold deep seawater), refreshing the coast in shallow, local areas (a few kilometres and with very variable location); this summer phenomenon is known in Málaga as "terral” (Senciales-González, 2007).

\section{Discussion}

The world climatic data net has a very low density if the WMO criteria are strictly followed (WMO, 2018). This is the reason why studies all over the world use several methods to validate scarce data, to ensure they are sufficiently representative of local climatic conditions. Thus, using the NR (when there are several reference stations) and SNHT (when there are only one or two), it is possible to validate data until reaching the mentioned criteria. In addition, these methods can be used to find inhomogeneities that lead us to discard series or parts of them, refining the available information (Peterson and Owen, 2005; Alexandersson, 2001; Aguilar-Anfrons et al., 2002). Nevertheless, in spite of the statistical validity, there is always the question about time-series to forecast beyond the measured data: is it truly valid in an urban scenario of climate change?

Three complete series have been extrapolated and the results can be considered valid and credible, and consistent with the nearby stations. Specifically, the city of Málaga is delimited by a mountainous relief, the sea and one fluvial valley which channels the continental winds. Regardless the type of urbanization, annual mean temperatures and maximum daily temperatures reveal an inverse gradient in the urban zone, as occurs in several other studies (Miao et al., 2015; García-Guadalupe et al., 2012). However, the average minimum daily temperatures keep a logical gradient $\left(-0.34 \cdot 100 \mathrm{~m}^{-1}\right)$. Probably, the effect of maritime breezes can refresh the lowest areas of the city in day time and during the summer (with predominance of maritime winds), attenuating the warmest values; whilst, at night and during the winter, the predominance of continental winds keeps a normal gradient and accentuates the thermal amplitude (Rodrigo-Comino et al., 2014).

An increase in temperature is usually caused by an increase in pollution (Cao et al., 2016; Li et al., 2018), and high levels of pollution damages the touristic attraction 
of the city. The municipality of Malaga offers information about pollution in many neighbourhoods (Smart Data Málaga, 2019), but it does not show any metadata (hour, date, data series); those data have been consulted, but not considered for this research. However, it seems clear that the main pollution centres are located in the main avenues and the urban centre, given the fact that Málaga is a city with few green areas: $6 \%$ of the total area of the city, and $7.6 \mathrm{~m}^{2}$.hab ${ }^{-1}$ (Fuller and Gaston, 2009; Ayuntamiento de Málaga, 2015; Russo and Cirella, 2018). Nevertheless, a slightly "cool effect" can be seen in a green area called "Castillo de Gibralfaro" as has been revealed in other cities with castles and medieval fortresses (Pérez-González et al., 2003; Farina, 2012; Edmondson et al., 2016). This is considered to be a "cool island", where the effect of the elevation compared to the city (130 m a.s.1.), the absence of buildings (except the castle) and its forest cover are combined, demonstrating the importance of green areas.

Regarding the results of the current research, the average of the series used was evaluated, using climatic values, and has been statistically normalized and validated. The SNHT method is commonly used (Alexandersson, 2001; Aguilar-Anfrons et al., 2002; Domonkos and Štěpánek, 2009), but the NR method is preferred to improve statistical validity (Paulhus and Kohler, 1952), especially, in areas characterised by frequent topographical variations. The weather types that determine the maximum and minimum values are usually due to continental flows (Rasilla-Álvarez, 2003; Rodrigo et al., 2019). Málaga City studies have previously considered Málaga Airport as the climatic station of reference, but numerous stations of Málaga city have a better adjustment with other stations than that, which is located at the bottom of the Guadalhorce valley and experiences frequent thermal inversions and continental flows. It is necessary to correctly select the reference stations before they are used.

Co-kriging (Universal Kriging) was found to be a useful tool that allows topographical variables to be compared to other types of environmental variables, which is particularly useful in the case of temperatures with respect to relief (Crawford, 2001). Plotting maps with this tool obtained satisfactory results, which shows the effect of UHI throughout the city, depending on both temperatures and relief.

In order to assist with urban planning, it would be necessary to increase the number of weather stations and until reaching statistical validity (Domonkos and Štěpánek, 2009; Schneider, 2001). This is obligatory to detect urban areas where urgent interventions are necessary, either due to a shortage of green areas or because of an inadequate construction model to mitigate UHI (Nouri et al., 2017-1). This is the case in Málaga. It is also necessary to consider the distance to the sea and the height with respect to sea level to address thermal variability as much as it would be convenient to differentiate seasonal, monthly, daily or, even, hourly values, highlighting differences between urban and rural areas in terms of winds, humidity and temperatures.

This highlights the need to consider non-thermometric aspects such as elevation, orientation, or position, as well as the growth of the population (Nouri et al., 2017-2) and the types of the built environment and land cover (Stewart et al., 2014). Accordingly, 
UHI studies in cities located in complex terrain need an adjustment for relief and other aspects, such as distance to bodies of water (sea, lake, river) (Ketterer and Matzarakis, 2014; Martín-Vide et al., 2015; Ribeiro et al., 2018).

Urban growth could reduce the above-mentioned "cool island", increasing the UHI if this growth is not accompanied by an increase in green areas. It is necessary to analyse the parallel evolution of urban growth and increasing temperatures over the past 30 years. This will be the subject of future research.

Among the above-mentioned methods studying the UHI, it is necessary to highlight several expressions to calculate it according to the human population (Oke, 1978; Karl et al., 1988; Torok et al., 2001) or type of urbanisation (Stewart et al., 2014). Such studies obtain very different results, from $0.7{ }^{\circ} \mathrm{C}$ (Cao et al., 2016) to $20^{\circ} \mathrm{C}$ (Menberg et al., 2013), although there are certain differences among measurement methods: satellite versus ground devices. In a similar study if UHI in Ibiza (SerraPardo, 2007), a medium value of the difference between urban and rural areas of $3.2^{\circ} \mathrm{C}$ was observed. In the city of Málaga, the highest value of UHI is reached in average minimum temperatures of August: $4.4{ }^{\circ} \mathrm{C}$, but the mean annual data are reduced to $2{ }^{\circ} \mathrm{C}$. It is important to highlight that the city of Málaga has a population almost four times bigger than Ibiza. Three methods were applied to compare UHI and population: Oke (1978), Karl et al. (1988) and Torok et al. (2001). The last method obtains the closest results to the data measured in Málaga when average values are used. These methods consider an increasing of UHI when population increases but do not consider any other effect (trees, topography, closeness to the sea...). When the values of UHI for a given time (fixed hour and date) are analysed, a value of $9.1{ }^{\circ} \mathrm{C}$ is seen for Málaga. This instantaneous maximum exceeds the values calculated by Oke method. Nevertheless, it is necessary to highlight that differences greater than $9{ }^{\circ} \mathrm{C}$ between stations 9 and 10 is only present in $0.42 \%$ of the cases, while the weighted average difference between both stations is $2.3{ }^{\circ} \mathrm{C}$, the value that is reached in at least $30 \%$ of cases. In addition, the role of maritime breezes could reduce the effect of UHI in those areas next to the sea, while it increases in high areas and far from the sea, explaining the above-mentioned inverse gradient and the maximum differences between urban and rural stations. That is why this study emphasizes the use of average values to clarify that UHI in Málaga city is not only a meteorological event but a frequent, climatic phenomenon.

\section{Challenges, implications and main conclusions}

The usefulness of this type of study is evident. For example, some authors have emphasized the relationships between socioeconomic pattern, green land-cover and urban planning (Buyantuyev and Wu, 2010; Farina, 2012) or applied to climatic change scenarios (Shimoda, 2003), or relations between UHI and health (Jendritzky and Tinz, 2009). Finally, there are several studies that focus on the relationships between comfort and tourism, with a worsening of the tourist experience due to the increase of thermal values (Rutty and Scott, 2015). In this context, the current research is an introduction for further studies focusing on urban and touristic planning in the 
city of Málaga, where the shortage of green zones coincides with higher thermal values in average minimum daily of temperatures and, in general, in most of the instantaneous values throughout the city, that is, not located only in the centre of the city and not strictly related to the type of building. This reveals the need for increasing green zones, especially in higher areas, where thermal values are higher. As some researchers have shown, an increase in thermal values implies an increase in water and energy demand (Gondhalekar and Ramsauer, 2017; Núñez-Peiró et al., 2017; Salvati et al., 2017). In the case of the city of Málaga, whose water reserves are located in areas where climate change scenarios provide for reductions in rainfall (Burke et al., 2006; Ruiz-Sinoga et al., 2011) and the consequent increase in the price of energy, it is fundamental to control the increase of thermal values. This increase can also lead to a worsening of the climate welfare indices, and, therefore, a reduction in tourism, one of the main sources of income of the city.

We highlight the following conclusions of this study:

(i) Using the NR (when there are several reference stations) and SNHT (when there are only one or two reference stations), it is possible to validate data until reaching WMO criteria, and it is possible to find inhomogeneities. In addition, co-kriging is a useful tool that allows topographical variables to be compared to temperature data.

(ii) The effect of maritime breezes modifies and reverses the normal thermal gradients in Málaga city and moves the maximum values of UHI to higher and interior areas of the city, although the thermal values of all urban stations at night always remain higher than those from rural stations. However, this effect overturns the role of LCZs at midday. It is necessary to increase the density of the network of weather stations to identify those areas with the highest UHI, arguably those with few or no plants, and dense, tall buildings.

(iii) UHI in Málaga city is not only a meteorological event but a frequent, climatic phenomenon. Thus, the average minimum temperatures in August in Málaga city are $4.4{ }^{\circ} \mathrm{C}$ higher than in rural zones; using mean annual data reduces this difference to $2{ }^{\circ} \mathrm{C}$, but the values of UHI for a given time (fixed hour and date) in Málaga can reach $9.1{ }^{\circ} \mathrm{C}$. Maximum differences between urban and rural zones using fixed hour data are reached in autumn and winter.

\section{Acknowledgements}

We would like to thank REDIAM (Junta de Andalucía) the availability of climatic data.

\section{References}

AEMET 2019. Guía resumida del clima en España (1981-2010). In: www.aemet.es.

AENA 2018. Estadísticas de tráfico aéreo. Available in http://www.aena.es/es/corporativa/ estadisticas-trafico-aereo.html.

Aguilar-Anfrons, E., Brunet, M., Saladié-Borraz, Ò., Sigró-Rodríguez, J., López-Olivares, D. 2002. Hacia una aplicación óptima del Standard Normal Homogeneity Test para la 
homogeneización de series de temperatura. In: J.M. Cuadrat, S.M. Vicente, M.A. Saz (Eds.), La información climática como herramienta de gestión ambiental. VII Reunión Nacional de Climatología, pp. 17-34.

Alcoforado, M.J., Andrade, H. 2006. Nocturnal urban heat island in Lisbon (Portugal): main features and modelling attempts. Theoretical and Applied Climatology 84 (1), 151-159. https://doi.org/10.1007/s00704-005-0152-1.

Alexandersson, H. 2001. Homogenisation of climate data, difficult but necessary. In: M. Brunet, D. López Bonillo, Detecting and Modelling Regional Climate Change. Springer, Berlin, pp. 3-12. https://doi.org/10.1007/978-3-662-04313-4_1.

Alexandersson, H., Moberg, A. 1997. Homogenization of Swedish temperature data. Part I: Homogeneity test for linear trends. International Journal of Climatology 17 (1), 25-34. https://doi.org/10.1002/(SICI)1097-0088(199701)17:1<25::AID-JOC103>3.0.CO;2-J.

Aniello, C., Morgan, K., Busbey, A., Newland, L. 1995. Mapping micro-urban heat islands using LANDSAT TM and a GIS. Computers \& Geosciences 21 (8), 965-969. https://doi. org/10.1016/0098-3004(95)00033-5.

Ayuntamiento de Málaga. 2015. Territorio y configuración de la ciudad. Agenda urbana de Málaga, 2015. Área de Sostenibilidad Ambiental - Observatorio de Medio Ambiente Urbano (OMAU), 56 pp.

Bahi, H., Rhinane, H., Bensalmia, A., Fehrenbach, U., Scherer, D. 2017. Effects of urbanization and seasonal cycle on the surface urban heat island patterns in the coastal growing cities: A case study of Casablanca, Morocco. Remote Sensing 9 (1), 91. https://doi.org/10.3390/rs8100829.

Barrera-Escoda, A. 2004. Técnicas de completado de series mensuales y aplicación al estudio de la influencia de la NAO en la distribución de la precipitación en España. Universidad de Barcelona. Departamento de Astronomía y Meteorología. Grupo de Análisis de Situaciones Meteorológicas Adversas, 96 pp.

Barry, R.G., Chorley, R.J. 2009. Atmosphere, Weather and Climate. Ed. 1, Routledge, London New York, 536 pp.

Bello Fuentes, V.B. 1994. La Isla de Calor y los Usos del Suelo en Guadalajara. Serie Geográfica, 4, 83-97.

Burke, E.J., Brown, S.J., Christidis, N. 2006. Modeling the Recent Evolution of Global Drought and Projections for the Twenty-First Century with the Hadley Centre Climate Model. Journal of Hydrometeorology 7, 1113-1125. https://doi.org/10.1175/JHM544.1.

Buyantuyev, A., Wu, J. 2010. Urban heat islands and landscape heterogeneity: linking spatiotemporal variations in surface temperatures to land-cover and socioeconomic patterns. Landscape Ecology 25 (1), 17-33. https://doi.org/10.1007/s10980-009-9402-4.

Cao, C., Lee, X., Liu, S., Schultz, N., Xiao, W., Zhang, M., Zhao, L. 2016. Urban heat islands in China enhanced by haze pollution. Nature Communications 7, 12509. https://doi.org/10.1038/ ncomms 12509.

Capelli de Steffens, A.M., Campo de Ferreras, A.M., Piccolo, M.C. 2005. El clima urbano de Bahía Blanca. Ed. Dunken, 184 pp.

Chandler, T.J. 1965. The Climate of London. Hutchinson, 292 pp.

Chen, X., Jeong, S.-J. 2018. Shifting the urban heat island clock in a megacity: A case study of Hong Kong. Environmental Research Letters 13 (1),014014. https://doi.org/10.1088/1748-9326/aa95fb.

Chen, X.-L., Zhao, H.-M., Li, P.-X., Yin, Z.-Y. 2006. Remote sensing image-based analysis of the relationship between urban heat island and land use/cover changes. Remote Sensing of Environment 104 (2), 133-146. https://doi.org/10.1016/j.rse.2005.11.016.

Corumluoglu, O., Asri, I. 2015. The effect of urban heat island on Izmir's city ecosystem and climate. Environmental Science and Pollution Research 22 (5), 3202-3211. https://doi. org/10.1007/s11356-014-2874-z. 
Crawford, C.A.G. 2001. Geostatistics and Spatial Hierarchical Modeling (Interuniversity Consortium on Social and Political Research, University of Michigan). Workshop on Spatial Analysis in Social Research, National Center for Environmental Health, Centers for Disease Control and Prevention, pp. 1-27.

Domonkos, P., Štěpánek, P. 2009. Statistical characteristics of detectable inhomogeneities in observed meteorological time series. Studia Geophysica et Geodaetica 53 (2), 239-260. https://doi.org/10.1007/s11200-009-0015-9.

Edmondson, J.L., Stott, I., Davies, Z.G., Gaston, K.J., Leake, J.R. 2016. Soil surface temperatures reveal moderation of the urban heat island effect by trees and shrubs. Scientific Reports 6 , 33708. https://doi.org/10.1038/srep33708.

Eischeid, J.K., Pasteris, P.A., Diaz, H.F., Plantico, M.S., Lott, N.J. 2000. Creating a Serially Complete, National Daily Time Series of Temperature and Precipitation for the Western United States. Journal of Applied Meteorology 39 (9), 1580-1591. https://doi.org/10.1175/15200450(2000)039<1580:CASCND>2.0.CO;2.

Farina, A. 2012. Exploring the relationship between land surface temperature and vegetation abundance for urban heat island mitigation in Seville, Spain. LUMA-GIS Thesi,. LUP Student Paper, Lund University, 15, 58 pp. Available in: http://lup.lub.lu.se/student-papers/ $\operatorname{record} / 3460284$.

Fuller, R.A., Gaston, K.J. 2009. The scaling of green space coverage in European cities. Biological Letters 5 (3), 352-355. https://doi.org/10.1098/rsbl.2009.0010.

García-Guadalupe, M., Ramírez-Sánchez, H.U., Ulloa-Godínez, H., Arias, S., Pérez, A. 2012. Las inversiones térmicas y la contaminación atmosférica en la Zona Metropolitana de Guadalajara (México). Investigaciones Geográficas 58, 9-29. https://doi.org/10.14198/ INGEO2012.58.01.

Giovannini, L., Zardi, D., de Franceschi, M., Chen, F. 2014. Numerical simulations of boundarylayer processes and urban-induced alterations in an Alpine valley. International Journal of Climatology 34 (4), 1111-1131. https://doi.org/10.1002/joc.3750.

Goldreich, Y. 1984. Urban topoclimatology. Progress in Physical Geography: Earth and Environment 8 (3), 336-364. https://doi.org/10.1177/030913338400800302.

Gomes, W.P., Amorim, M.C. de C.T. 2015. Análisis de la isla de calor de superficie en la ciudad de Ubatuba, Brasil. In: J. Olcina, A.M. Rico, E. Molto (Eds.), Clima, sociedad, riesgos y ordenación del territorio. Asociación Española de Climatología, 121-130.

Gondhalekar, D., Ramsauer, T. 2017. Nexus City: Operationalizing the urban Water-Energy-Food Nexus for climate change adaptation in Munich, Germany. Urban Climate 19, 28-40. https:// doi.org/10.1016/j.uclim.2016.11.004.

González-Hidalgo, J.C, De Luis, M., Štepánek, P., Raventós J. Cuadrat, J.M. 2002. Reconstrucción, estabilidad y proceso de homogeneización de series de precipitación en ambientes de elevada variabilidad pluvial. In: J.M. Cuadrat, S.M. Vicente, M.A. Saz (Eds), La información climática como herramienta de gestión ambiental. VII Reunión Nacional de Climatología, pp. 47-57.

Howard, L. 1818. The Climate of London: Deduced from Meteorological Observations, Made at Different Places in the Neighbourhood of the Metropolis. W. Phillips.

Hufty, A. 1975. Gradients verticaux de température et combinaisons des éléments du temps. Annales de géographie 84, 526-542.

Instituto de Estadística y Cartografía (IECA) 2018. Nomenclátor de entidades y núcleos de población de Andalucía. Junta de Andalucía. Available in: http://www.juntadeandalucia.es/ institutodeestadisticaycartografia/nomenclator/index.htm.

Jendritzky, G., Tinz, B. 2009. The thermal environment of the human being on the global scale. Global Health Action 2, 1-12. https://doi.org/10.3402/gha.v2i0.2005. 
Jhaldiyal, A., Gupta, K., Gupta, P.K., Thakur, P., Kumar, P. 2018. Urban Morphology Extractor: A spatial tool for characterizing urban morphology. Urban Climate 24, 237-246. https://doi. org/10.1016/j.uclim.2018.04.003.

Junta de Andalucía. 2018. "REDIAM". Subsistema de información de climatología ambiental (Clima). Available in: http://www.juntadeandalucia.es/medioambiente/servtc5/WebClima/?lr=lang_es.

Karl, T.R., Diaz, H.F., Kukla, G. 1988. Urbanization: Its detection and effect in the United States climate record. Journal of Climate 1 (11), 1099-1123. https://doi.org/10.1175/15200442(1988)001<1099:UIDAEI>2.0.CO;2.

Ketterer, C., Matzarakis, A. 2014. Human-biometeorological assessment of the urban heat island in a city with complex topography - The case of Stuttgart, Germany. Urban Climate 10, 573-584. https://doi.org/10.1016/j.uclim.2014.01.003.

Li, H., Meier, F., Lee, X., Chakraborty, T., Liu, J., Schaap, M., Sodoudi, S. 2018. Interaction between urban heat island and urban pollution island during summer in Berlin. Science of The Total Environment 636, 818-828. https://doi.org/10.1016/j.scitotenv.2018.04.254.

Lin, C.Y., Chen, F., Huang, J.C., Chen, W.C., Liou, Y.A., Chen, W.N., Liu, S.C. 2008. Urban heat island effect and its impact on boundary layer development and land-sea circulation over northern Taiwan. Atmospheric Environment 42 (22), 5635-5649. https://doi.org/10.1016/j. atmosenv.2008.03.015.

Lin, T.P., Matzarakis, A. 2008. Tourism climate and thermal comfort in Sun Moon Lake, Taiwan. International Journal of Biometeorology 52 (4), 281-290. https://doi.org/10.1007/s00484007-0122-7.

Lo, C.P., Quattrochi, D.A., Luvall, J.C. 1997. Application of high-resolution thermal infrared remote sensing and GIS to assess the urban heat island effect. International Journal of Remote Sensing 18 (2), 287-304. https://doi.org/10.1080/014311697219079.

Marín-Cots, P., Sánchez-Teba, E.M., Molina-Conde, I. 2008. Aproximación al escenario de cambio climático en la ciudad de Málaga. Composición y estudio de series estadísticas. Ayuntamiento de Málaga. Servicio de Programas. Observatorio del Medio Ambiente Urbano, 35.

Martín-Vide, J., Sarricolea, P., Moreno-García, M.C. 2015. On the definition of urban heat island intensity: the "rural" reference. Frontiers in Earth Science 3 (24), 1-3. https://doi. org/10.3389/feart.2015.00024.

Mason, N.W.H., Palmer, D.J., Romera, A., Waugh, D., Mudge, P.L. 2017. Combining field experiments and predictive models to assess potential for increased plant diversity to climate-proof intensive agriculture. Ecology and Evolution 7 (13), 4907-4918. https://doi. org/10.1002/ece3.3028.

Matzarakis, A. 2014. Transfer of climate data for tourism applications - The Climate-Tourism/ Transfer-Information-Scheme. Sustainable Environmental Research 24 (4), 273-280.

Mayer, H., Höppe, P. 1987. Thermal comfort of man in different urban environments. Theoretical and Applied Climatology 38 (1), 43-49. https://doi.org/10.1007/BF00866252.

McCarthy, M.P., Best, M.J., Betts, R.A. 2010. Climate change in cities due to global warming and urban effects. Geophysical Research Letters 37 (LO9705), 1-5. https://doi. org/10.1029/2010GL042845.

McKitrick, R.R., Michaels, P.J. 2007. Quantifying the influence of anthropogenic surface processes and inhomogeneities on gridded global climate data. Journal of Geophysical Research: Atmospheres 112 (D24S09), 1-14. https://doi.org/10.1029/2007JD008465.

Menberg, K., Bayer, P., Zosseder, K., Rumohr, S., Blum, P. 2013. Subsurface urban heat islands in German cities. Science of The Total Environment 442, 123-133. https://doi.org/10.1016/j. scitotenv.2012.10.043. 
Miao, Y.,Liu, S.,Zheng, Y., Wang, S., Chen, B. 2015.Numerical Study of the Effects of Topography and Urbanization on the Local Atmospheric Circulations over the Beijing-Tianjin-Hebei, China. Advances in Meteorology 7, 1-16. https://doi.org/10.1155/2015/397070.

Mirón-Pérez, I.J., Montero-Rubio, J.C., Criado-Álvarez, J.J., Gutiérrez-Ávila, G., Paredes-Beato, D., Mayoral-Arenas, S., Linares-Gil, C. 2006. Tratamiento y estudio de series de temperatura para su aplicación en salud pública: El caso de Castilla-La Mancha. Revista Española de Salud Pública 80 (2), 113-124.

Moreno-García, M.C., Serra, J.A. 2016. El estudio de la isla de calor urbana en el ámbito mediterráneo: una revisión bibliográfica. Geocrítica, Biblio3W 2, 1-32.

Ningrum, W. 2018. Urban Heat Island towards Urban Climate. IOP Conference Series: Earth and Environmental Science 118, 1-6. https://doi.org/10.1088/1755-1315/118/1/012048.

Nouri, A.S., Costa, J.P., Matzarakis, A. 2017. Examining default urban-aspect-ratios and skyview-factors to identify priorities for thermal-sensitive public space design in hot-summer Mediterranean climates: The Lisbon case. Building and Environment 126, 442-456. https:// doi.org/10.1016/j.buildenv.2017.10.027.

Nouri, A.S., Costa, J.P. 2017. Placemaking and climate change adaptation: new qualitative and quantitative considerations for the "Place Diagram". Journal of Urbanism: International Research on Placemaking and Urban Sustainability 10 (3), 356-382. https://doi.org/10.10 80/17549175.2017.1295096.

Núñez-Peiró, M., Sánchez-Guevara, C., Neila-González, F.J. 2017. Actualización de la isla de calor urbana de Madrid y su influencia en la simulación energética de edificios. Actas 3er. Congreso Internacional de Construcción Sostenible y Soluciones Eco-Eficientes, pp. 890-901.

Oke, T.R. 1978. Boundary Layer Climates. Methuen, 372 pp.

Paulhus, J.L.H., Kohler, M.A. (1952). Interpolation of missing precipitation records. Monthly Weather Review 80 (8), 129-133. https://doi.org/10.1175/1520-0493(1952)080<0129:IOM $\mathrm{PR}>2.0 . \mathrm{CO} ; 2$.

Pérez-González, M.E.P., García-Rodríguez, M.P., Guerra-Zaballos, A. 2003. Análisis del clima urbano a partir de imágenes de satélite en el centro peninsular español. Anales de Geografía de la Universidad Complutense 23, 187-206.

Peterson, T.C., Owen, T.W. (2005). Urban heat island assessment: Metadata are important. Journal of Climate 18 (14), 2637-2646. https://doi.org/10.1175/JCLI3431.1.

Prieto, L., García-Herrera, R., Díaz, J., Hernández, E., del Teso, T. 2004. Minimum extreme temperatures over Peninsular Spain. Global and Planetary Change 44 (1), 59-71. https://doi. org/10.1016/j.gloplacha.2004.06.005.

Rasilla-Álvarez, D.F. 2003. Aplicación de un método de clasificación sinóptica a la Península Ibérica. Investigaciones Geográficas 30, 27-45. https://doi.org/10.14198/INGEO2003.30.07.

Ribeiro, F.N.D., Oliveira, A.P. de, Soares, J., Miranda, R.M. de, Barlage, M., Chen, F. 2018. Effect of sea breeze propagation on the urban boundary layer of the metropolitan region of Sao Paulo, Brazil. Atmospheric Research 214, 174-188. https://doi.org/10.1016/j. atmosres.2018.07.015.

Rizwan, A.M., Dennis, L.Y.C., Liu, C. 2008. A review on the generation, determination and mitigation of Urban Heat Island. Journal of Environmental Sciences 20 (1), 120-128. https:// doi.org/10.1016/S1001-0742(08)60019-4.

Rodrigo-Comino, J. 2012. Cuantificación de los gradientes térmicos a nivel superficial a lo largo del Rheinland-Pfalz (Renania-Palatinado, Alemania). Baetica, Estudios de Geografía e Historia 35, 75-97.

Rodrigo-Comino, J., Senciales-González, J.M., González-Moreno, J.M. 2014. La necesidad de considerar los riesgos climáticos en la introducción de cultivos tropicales en latitudes medias. 
El mango en el valle del Guadalhorce (Málaga). Investigaciones Geográficas 62, 127-141. https://doi.org/10.14198/INGEO2014.62.09.

Rodrigo-Comino, J., Senciales-González, J.M., Sillero-Medina, J.A., Gyasi-Agyei, Y., RuizSinoga, J.D., Ries, J. B. 2019. Analysis of weather-type-induced soil erosion in cultivated and poorly managed abandoned sloping vineyards in the Axarquía region (Málaga, Spain). Air, Soil and Water Research 12, 1-11. https://doi.org/10.1177/1178622119839403.

Ruiz-Sinoga, J.D., García-Marín, R., Martínez-Murillo, J.F., Gabarrón-Galeote, M.A. 2011. Precipitation dynamics in southern Spain: Trends and cycles. International Journal of Climatology 31 (15), 2281-2289. https://doi.org/10.1002/joc.2235.

Russo, A., Cirella, G.T. 2018. Modern Compact Cities: How Much Greenery Do We Need? Int J Environ Res Public Health 15 (10), 2180, 1-15. https://doi.org/10.3390/ijerph15102180.

Rutty, M., Scott, D. 2015. Bioclimatic comfort and the thermal perceptions and preferences of beach tourists. International Journal of Biometeorology 59 (1), 37-45. https://doi. org/10.1007/s00484-014-0820-x.

Salvati, A., Coch, H., Cecere, C. 2017. Assessing the urban heat island and its energy impact on residential buildings in Mediterranean climate: Barcelona case study. Energy and Buildings 146, 38-54. https://doi.org/10.1016/j.enbuild.2017.04.025.

Sánchez-Guevara Sánchez, C., Núñez Peiró, M. Neila González, F.J. 2017. Urban Heat Island and Vulnerable Population. The case of Madrid. In: P. Mercader Moyano (Ed.), Sustainable Development and Renovation in Arquitecture, Urbanism and Engineering. Springer International Publishing, Cham, Switzerland, pp. 3-13.

Schneider, T. 2001. Analysis of Incomplete Climate Data: Estimation of Mean Values and Covariance Matrices and Imputation of Missing Values. Journal of Climate 14 (5), 853-871. https://doi.org/10.1175/1520-0442(2001)014<0853:AOICDE>2.0.CO;2.

Senciales González, J.Mª . 2007. El clima en la provincia de Málaga. In: J.J. Durán Valsero (Coord.), Atlas Hidrogeológico de la provincia de Málaga, Instituto Geológico y Minero de España - Diputación provincial de Málaga, Madrid. Vol I, pp. 50-58.

Serra Pardo, J.A. 2007. Estudio de la isla de calor de la ciudad de Ibiza. Investigaciones Geográficas $44,55-73$.

Shimoda, Y. 2003. Adaptation measures for climate change and the urban heat island in Japan's built environment. Building Research \& Information 31 (3-4), 222-230. https://doi.org/10.1 080/0961321032000097647.

Smart Data Málaga. Zonas verdes de Málaga. Datos de Calidad del Aire. Available at http:// smartdatamalaga.com/zonas-verdes-malaga (last access: 18/01/2019).

Sobrino, J.A., Oltra-Carrió, R., Sòria, G., Jiménez-Muñoz, J.C., Franch, B., Hidalgo, V., Mattar, C., Julien, Y., Cuenca, J., Romaguera, M. Gómez, J.A., De Miguel, E., Bianchi, R., Paganini, M. 2013. Evaluation of the surface urban heat island effect in the city of Madrid by thermal remote sensing. International Journal of Remote Sensing 34, (9-10), 3177-3192. http:// dx.doi.org/10.1080/01431161.2012.716548.

Stewart, I.D., Oke, T.R., Krayenhoff, E.S. 2014. Evaluation of the 'local climate zone' scheme using temperature observations and model simulations. International Journal of Climatology 34 (4), 1062-1080. https://doi.org/10.1002/joc.3746.

Suomi, J. 2014. Characteristics of urban heat island (UHI) in a high-latitude coastal city - a case study of Turku, SW Finland. Turku, 295, 9789512959112, 70 pp.

Tabony, R.C. 1985. Relations between minimum temperature and topography in Great Britain. Journal of Climatology 5 (5), 503-520. https://doi.org/10.1002/joc.3370050504.

Thompson, W.T., Holt, T., Pullen, J. 2007. Investigation of a sea breeze front in an urban environment. Quarterly Journal of the Royal Meteorological Society 133 (624), 579-594. https://doi.org/10.1002/qj.52. 
Torok, S.J., Morris, C.J.G., Skinner, C., Plummer, N. 2001. Urban heat island features of southeast Australian towns. Australian Meteorological Magazine 50, 1-13.

Vicente-Serrano, S., Cuadrat-Prats, J.; Saz-Sánchez, M. 2005. Spatial patterns of the urban heat island in Zaragoza (Spain). Climate Research 30, 61-69.

WMO 2018. WMO confirms 2017 among the three warmest years on record. Available at https:// public.wmo.int/en/media/press-release/wmo-confirms-2017-among-three-warmest-yearsrecord (last access: 12/09/2018).

Zeleňáková, M., Purcz, P., Hlavatá, H., Blišt’an, P. 2015. Climate Change in Urban Versus Rural Areas.Procedia Engineering, 119,1171-1180.https://doi.org/10.1016/j.proeng.2015.08.968. 